\title{
Assessment of Genetic and Immunological Factors Associated with Hepatitis C Infection in Saudi Hemodialysis Patients
}

\author{
Alhusain J. Alzahrani ${ }^{*}$, Obeid E. Obeid ${ }^{2}$, Amein K. Alali ${ }^{3}$, Samir Al-Mueilo", \\ Yazeed Al-Sheihk ${ }^{1}$, Maaz Ulhasan ${ }^{5}$ \\ ${ }^{1}$ Department of Clinical Laboratory Sciences, College of Applied Medical Sciences, King Saud University, \\ Riyadh, KSA \\ ${ }^{2}$ Department of Microbiology, College of Medicine, University of Dammam, Dammam, KSA \\ ${ }^{3}$ Department of Biochemistry, College of Medicine, University of Dammam, Dammam, KSA \\ ${ }^{4}$ Department of Internal Medicine, College of Medicine, University of Dammam, Dammam, KSA \\ ${ }^{5}$ Department of General Surgery, King Fahad Medical City, Riyadh, KSA \\ Email: ajalzahrani@ksu.edu.sa
}

Received 6 January 2014; revised 10 February 2014; accepted 18 February 2014

Copyright (C) 2014 by authors and Scientific Research Publishing Inc.

This work is licensed under the Creative Commons Attribution International License (CC BY).

http://creativecommons.org/licenses/by/4.0/

(c) (i) Open Access

\section{Abstract}

The association of human leukocyte antigen (HLA) genotype and hepatitis C virus (HCV) infection has been reported in many populations. In addition, the HLA genotype distribution has been found to differ according to ethnicity. Currently, there are no published data concerning this relationship in the Saudi population. Therefore, the primary objective of this study was to determine the relationship between HLA genotype and HCV infection in a group of haemodialysis patients in a tertiary hospital in the Eastern Province of Saudi Arabia. A total of 152 haemodialysis patients and 160 controls were enrolled in the study. The patient group included 91 males and 61 females with a mean age of 48 years, who had been on haemodialysis for a period of 6 months to five years. The control group was randomly selected from donors attending the blood bank and included 155 males and five females with a mean age of 38 years. Of the patient group, $27(17.8 \%)$ were found to have HCV antibodies by EIA. The seropositivity was confirmed by RIBA and by RT-PCR. The average viral load was $15 \times 10^{3}$ HCV RNA per $10 \mu$ l of plasma. The predominant HCV genotype was found to be genotype 4. HLA-class I and HLA class II were screened in $27 \mathrm{HCV}$-positive patients and in 30 age and sex matched controls by polymerase chain reaction/sequence specific primers (PCR/SSP) method. Measurements of cytokines Interleukin-2, 10, IFN- $\gamma$ and TNF $\alpha$ showed that IL-2 level was 17.65 - $20.3 \mathrm{pg} / \mathrm{l}$; IFN- $\gamma$ was 22.15 - $41.1 \mathrm{pg} / \mathrm{l}$; TNF- $\alpha$ was 2.5 - $5.6 \mathrm{pg} / \mathrm{mL}$ and IL-10 was $10.7-14.8 \mathrm{pg} / \mathrm{mL}$. Measurement of CD markers showed the following: CD3 cells were measured. There was no correlation between infection with HCV and HLA type, cytokines levels and levels of "Corresponding author.

How to cite this paper: Alzahrani, A.J., et al. (2014) Assessment of Genetic and Immunological Factors Associated with Hepatitis C Infection in Saudi Hemodialysis Patients. Journal of Biosciences and Medicines, 2, 51-57. 
different cell populations. CD markers are similar in the HCV-positive and HCV-negative hemodialysis patients. Further analysis and comparisons are needed, especially between the cytokines and CD markers in the hemodialysis patients and control groups.

\title{
Keywords
}

\author{
HLA; CD Molecules; Cytokines; HCV; Hemodialysis Patients
}

\section{Introduction}

The number of patients on haemodialysis in Saudi Arabia is increasing with approximately 7020 patients currently receiving therapy [1] [2]. These patients are at higher risk of acquiring post-transfusion HCV infection. Anti-HCV prevalence rates among haemodialysis patients in Europe and Australia vary from $5.5 \%$ to $20 \%$, whilst in Japan and Taiwan the rates are between $18 \%$ to $47 \%$ [3]-[5].

Studies conducted in the 1990s using first-generation EIA tests revealed a prevalence of antibodies to hepatitis C virus (anti-HCV) among Saudi haemodialysis patients of 30.7\% to 48.7\% [6]-[10]. However, later studies that used second-generation EIA and confirmatory tests, found that the prevalence of anti-HCV ranged from $52.5 \%$ to $72.3 \%$ [11]-[15]. However, using HCV RNA assay, the prevalence rate reported by some centers reached as high as $94.7 \%$. Furthermore, Al Meshari et al. [16] reported a prevalence rate of anti-HCV of $88.4 \%$ among 43 haemodialysis patients. However, the same authors reported a prevalence rate of anti-HCV of $76 \%$ in the same group using third-generation recombinant immunoblot assay (RIBA 3.0).

A more recent study by Qadi et al. [2] on 81 Bahraini and 34 Saudi haemodialysis patients revealed a prevalence rate of HCV infection of $9.24 \%$ and $0.30 \%$, respectively. The most prevalent HCV genotypes in the Bahraini patients were HCV 1a/1b and HCV 4, while the prevalent genotypes in the Saudi patients were HCV 2/2a and HCV 4.

Although blood transfusion is the major cause of HCV infection in haemdialysis patients, a study by Alfurayh et al. [17] showed that nosocomial transmission of HCV in haemodialysis units also plays a significant role. In their study, HCV RNA was found on the hands of some personnel working with dialysis patients, in spite of adherence to standard precautions.

Currently, there is limited data published on the relationship between HLA types and HCV infection in the Saudi population. The aim of this study was to determine the relationship between the HLA types, immune status, and HCV infection among Saudi haemodialysis patients.

\section{Patients \& Methods}

\subsection{Patients and Subjects}

\subsubsection{Haemodialysis Patients}

All the haemodialysis patients in King Fahd Hospital of the University and King Fahd Medical Military Complex haemodialysis units from April 2008 to June 2010 were included in this study $(\mathrm{N}=152)$. The sample included new and pre-registered cases.

\subsubsection{Control Group}

The control group $(\mathrm{N}=160)$ was randomly selected from donors attending the blood bank from April 2008 to June 2010.

\subsection{Statistical Analysis}

Data were analyzed using SPSS version 16 statistical package. Correlation and association were derived using different parameters such as bivariate and multivariate analysis. A P-value of less than 0.05 was considered significant.

\subsection{Ethical Consideration}

This study was approved by the University of Dammam Ethical Committee. Signed written informed consent 
was obtained from each participant.

\subsection{Procedures}

\subsubsection{HCV Detection and Quantitation}

For HCV antibody detection, the collected sera was tested by Axsym hepatitis $C$ virus enzyme immunoassay 3.0 (HCV EIA) (Abbott Laboratories, Abbott Park, IL, 60064), and a recombinant immunoblot assay (RIBA) HCV 3.0 SIA (Chiron Corporation, Emeryville, CA 94608). Positive sera by both ELISA and RIBA was tested by PCR (Amplicor Roche Diagnostic System, Hoffman Laroche, Basle, Switzerland) using primers selected from the highly conserved 5'-UTR of HCV genome. Amplified products were electrophoresed, photographed and analyzed. Extraction and amplification of RNA was carried out according to the manufacturer's recommendations. Quantitation of viral load was performed using Amplicor Roche Diagnostic System, (Hoffman Laroche, Basle, Switzerland) and this was carried out according to the manufacturer's recommendations.

\subsubsection{HCV Genotyping}

Reverse Transcription-polymerase chain reaction (RT-PCR) using specific primers from 5'-UTR was performed, and the amplified products was genotyped/subtyped using commercial reverse phase hyperdization technique (Innolipa HCV, Innogenetics, Belgium) according to Simmond's classification [18].

\subsubsection{HLA Typing}

The HLA typing was done using DNA HLA typing procedures (PCR-sequence specific primers; PCR-SSP; One Lambda, Inc.).

\subsubsection{Lymphocyte Markers}

Whole blood samples were used. The following lymphocyte cell markers were analyzed: CD3, CD4, CD8, CD16, and CD19 using Flowcytometry (BD, USA). Values obtained from test groups were compared with normal range.

\subsubsection{Cytokine Pattern}

Serum levels of interleukin 2 and 10, interferon $\gamma$ and TNF $\alpha$ was assessed using ELISA kits (Binding Sites, UK).

\section{Results}

\subsection{Patients and Controls}

A total of 152 patients and 160 controls were recruited from hospitals in the Eastern Province of Saudi Arabia. Patients included hemodialysis and nephrology unit patients, including kidney transplant patients. The mean age of the patients was 48 years of age. They included 91 males and 61 females. The period of hemodialysis varied between 3 months to 5 years. The control group included blood donors attending the Blood Bank (mean age 38; 155 males and 5 females).

\subsection{Analysis of HCV Infection in Patients and Controls}

From the total of 152 patients, 27 were found to have HCV antibodies as determined by EIA (17.8\%). The seropositivity of these samples was confirmed by RIBA and RT-PCR. The average viral load was found to be $15 \times$ $10^{3}$ HCV RNA per $10 \mu$ l of plasma.

The pattern of HCV genotypes in the $27 \mathrm{HCV}$ positive patients was genotype 4:14 (51.9\%); genotype 1:11 (40.7\%) and genotype 5a: 2 (7.4\%). None of the subjects in the control groups tested positive for HCV antibodies or RNA.

\subsection{Determination of HLA Types in HCV-Positive Patients and Controls}

The 27 HCV-positive patients and 30 age and sex matched controls were screened for HLA-class I and HLA class II were screened in by polymerase chain reaction using sequence specific primers (PCR/SSP) method. The 
following types were detected: HLA-A9, A11, A19, A32, B5, B7, B8, B15, B17, B27, B35, B40, Bw6, Cw6, Cw7, DR1, DR2, DR3, DPB1, DQ1, DQB1, DRB1, DQP1, DR4, DR7, DR10, DR15, DR16, DR51 and DR53 (Table 1).

B7, CW6, CW7, and DR7 showed the highest gene frequencies of $22.1 \%, 17 \%, 9.2 \%$ and $26.9 \%$, respectively. However, haplotypes A9-B7, A11-B15, A32-B5, A12-B27, A19-Bw6, A32-B27 and B35-Cw7 showed the highest frequencies.

\subsection{Analysis of Cytokines and CD Molecules in Test and Control Groups}

Measurements of cytokines Interleukin-2, 10, IFN- $\gamma$ and TNF $\alpha$ showed that IL-2 level was 17.65 - $20.3 \mathrm{pg} / \mathrm{l}$; IFN- $\gamma$ was 22.15 - $41.1 \mathrm{pg} / \mathrm{l}$; TNF- $\alpha$ was 2.5 - $5.6 \mathrm{pg} / \mathrm{mL}$ and IL-10 was 10.7 - $14.8 \mathrm{pg} / \mathrm{mL}$ (Table 2). No statistically significant difference was found between cytokine levels in the test and control groups ( $p>0.05)$.

Measurement of CD markers (Table 3) showed the level of CD3 cells were between 1000 - $4000 \mu \mathrm{L}$; CD4 cells between 500 and $1600 \mu \mathrm{L}$; CD8 cells between 375 and $1100 \mu \mathrm{L}$; CD16 cells between $300-1530 \mu \mathrm{L}$ and CD19 cells between $132-523 \mu \mathrm{L}$. No statistically significant difference was found between levels of different cells in the test and control groups ( $\mathrm{p}>0.05$ ).

Table 1. Frequency of HLA class I and class II in test and controls.

\begin{tabular}{|c|c|c|c|}
\hline HLA class I type & Frequency & HLA class I type & Frequency \\
\hline A9 & 3 & A11 & 4 \\
\hline A19 & 5 & A32 & 4 \\
\hline B5 & 7 & B7 & 18 \\
\hline B8 & 5 & B15 & 3 \\
\hline B17 & 8 & B27 & 4 \\
\hline B35 & 6 & B40 & 2 \\
\hline Bw6 & 6 & Cw6 & 20 \\
\hline Cw7 & 19 & & \\
\hline HLA class II type & Frequency & HLA class II type & Frequency \\
\hline DR1 & 5 & DR2 & 5 \\
\hline DR3 & 4 & DPB1 & 3 \\
\hline DQ1 & 7 & DQB1 & 9 \\
\hline DRB1 & 3 & DQP1 & 8 \\
\hline DR4 & 11 & DR7 & 20 \\
\hline DR10 & 7 & DR15 & 11 \\
\hline DR16 & 5 & DR51 & 8 \\
\hline DR53 & 8 & & \\
\hline
\end{tabular}

Table 2. Cytokine levels (mean \pm SD).

\begin{tabular}{ccc}
\hline Cytokine & Level in test group & Level in control group \\
\hline IL-2 & $18.2 \pm 1.7 \mathrm{pg} / \mathrm{l}$ & $17.9 \pm 2.7 \mathrm{pg} / \mathrm{l}$ \\
IL-10 & $13.5 \pm 2.3 \mathrm{pg} / \mathrm{l}$ & $12.3 \pm 2.1 \mathrm{pg} / \mathrm{l}$ \\
IFN- $\gamma$ & $36.7 \pm 1.9 \mathrm{pg} / \mathrm{l}$ & $35.9 \pm 2.8 \mathrm{pg} / \mathrm{l}$ \\
TNF $\alpha$ & $3.8 \pm 1.5 \mathrm{pg} / \mathrm{l}$ & $3.1 \pm 1.8 \mathrm{pg} / \mathrm{l}$ \\
\hline
\end{tabular}


Table 3. CD molecules levels (mean \pm SD).

\begin{tabular}{ccc}
\hline Cell marker & Level in test group & Level in control group \\
\hline CD3 & $3800 \pm 108 / \mu \mathrm{L}$ & $3901 \pm 307 / \mu \mathrm{L}$ \\
CD4 & $1208 \pm 98 / \mu \mathrm{L}$ & $1353 \pm 227 / \mu \mathrm{L}$ \\
CD8 & $883 \pm 69 / \mu \mathrm{L}$ & $907 \pm 89 / \mu \mathrm{L}$ \\
CD16 & $505 \pm 57 / \mu \mathrm{L}$ & $699 \pm 97 / \mu \mathrm{L}$ \\
CD19 & $689 \pm 68 / \mu \mathrm{L}$ & $564 \pm 45 / \mu \mathrm{L}$ \\
\hline
\end{tabular}

\subsection{Correlation between HCV Infection and HLA Type and Immune Status in the Haemodialysis Patients}

No correlation was found between HCV positive and the control groups in relation to cytokines and CD markers, between infection with HCV and HLA type, and the cytokines levels.

\section{Discussion}

Two studies, which were conducted by Al-Mugeiren et al. [19] and Soyannwo et al. [20] on pediatric and adult haemodialysis Saudi patients, revealed HCV infection rates of $11.2 \%$ and $50 \%$, respectively. The HCV infection rate in the group of patients that we studied was $17.8 \%$. This difference could be attributed to a number of factors, including the length of time that the patient groups had been receiving haemodialysis.

In addition, previous studies conducted on Saudi haemodialysis patients with HCV infection have shown that genotype 4 is the most prevalent with a range of $36 \%$ to $55 \%$. In the present study, the most prevalent genotype was also found to be genotype 4 with a prevalence rate of $51 \%$, which is in line with the previous studies. Other prevalent genotypes in our study were genotype 1 and 5a, which is also in line with other studies.

A study by White et al. [21], which compared HLA types in the Gulf region, revealed that the prevalence of various HLA antigens differed significantly between various Gulf countries, including Oman, Kuwait and Saudi Arabia. The investigators also reported that HLA-DR2, which has the highest prevalence worldwide, had varying prevalence rates in the Gulf countries, with the Omani population having the highest prevalence of HLADR2. However, HLA-A, -B, -C and DR loci antigen frequencies were determined by Sheth et al. [22] on normal Saudi subjects showed that B21, CW4, CW7, and Dr7 had the highest frequencies, which is comparable to the present results.

A number of studies have reported a possible association between HLA genotype and HCV infection. Hadhoud et al. [23] studied this association in $146 \mathrm{HCV}$ positive renal transplantation patients and $122 \mathrm{HCV}$ negative individuals and reported a possible association between the expression of HLA alleles and HCV infection. Another study, by Fitzmaurice et al. [24], examined the relationship in a cohort of HCV patients and reported a potential protective impact of HLA-A on HCV infection. Cangussu et al. [25] reported that polymorphic residues presented on different $\mathrm{DRB} 1 * 11$ and/or DQB1*03 alleles were found to be responsible for resistance against HCV infection.

In the present study no association was found between HLA genotype and HCV infection in the Saudi cohort studied. This discrepancy could be due to the small sample size included in this study. To confirm whether there is an association a larger sample size needs to be included.

\section{Summary, Suggestions and Recommendations}

The prevalence of HCV infection and its association with HLA genotype were identified in 152 Saudi hemodialysis patients and in 160 controls. The level of cytokines and immune cells in the same cohort were studied. No association was found between different HLA alleles and HCV infection in this population. A larger multicentre study should be conducted to ascertain these results.

\section{Acknowledgments}

This work was partially supported by a grant from the National Plan for Science and Technology, King Abdula- 
ziz City for Science and Technology.

\section{References}

[1] Jondeby, M.S., De-Los Santos, G.G., Al-Ghamdi, A.M., Al-Hawas, F.A., Mousa, D.H., Al-Sulaiman, M.H. and Al-Khader, A.A. (2001) Caring for Hemodialysis Patients in Saudi Arabia. Past, Present and Future. Saudi Medical Journal, 22, 199-204.

[2] Qadi, A.A., Tamim, H., Ameen, G., Bu-Ali, A., Al-Arrayed, S., Fawaz, N.A. and Almawi, W.Y. (2004) Hepatitis B and Hepatitis C Virus Prevalence among Dialysis Patients in Bahrain and Saudi Arabia: A Survey by Serologic and Molecular Methods. American Journal of Infection Control, 32, 493-495. http://dx.doi.org/10.1016/j.ajic.2003.12.009

[3] Gilli, P., Moretti, M., Soffritti, S. and Menini, C. (1990) Anti-HCV Positive in Dialysis Units? Lancet, 336, $243-244$. http://dx.doi.org/10.1016/0140-6736(90)91766-4

[4] Willems, M., de Jong, G., Moshage, H., Verresen, L., Goubau, P., Desmyter, J. and Yap, S.H. (1991). Surrogate Markers Are Not Useful for Identification of HCV Carriers in Chronic Hemodialysis Patients. Journal of Medical Virology, 35, 303-306. http://dx.doi.org/10.1002/jmv.1890350417

[5] Sakamoto, N., Enomoto, N., Marumo, F. and Sato, C. (1993). Prevalence of Hepatitis C Virus Infection among LongTerm Hemodialysis Patients: Detection of Hepatitis C Virus RNA in Plasma. Journal of Medical Virology, 39, 11-15. http://dx.doi.org/10.1002/jmv.1890390104

[6] Saeed, A.A., Fairclough, D., Al-Admawi, A.M., Bacchus, R., Al-Raseed, A.M., et al. (1990) Hepatitis C Virus in Saudi Arabia: A Preliminary Survey. Saudi Medical Journal, 11, 331-332.

[7] Mitwalli, A., Al-Mohaya, S., Al-Wakeel, J., El Gamal, H., Rotimi, V., et al. (1992) Hepatitis C in Chronic Renal Failure Patients. American Journal of Nephrology, 12, 288-291. http://dx.doi.org/10.1159/000168462

[8] Ayoola, E.A., Huraib, S., Arif, M., Al-Faleh, F.Z., Al-Rashed, R., et al. (1991) Prevalence and Significance of Antibodies to Hepatitis C Virus among Saudi Hemodialysis Patients. Journal of Medical Virology, 35, 155-159. http://dx.doi.org/10.1002/jmv.1890350303

[9] Al-Nasser, M.N., Al-Mugeiren, M.A., Assuhaimi, S.A., Obineche, E., Onwabalili, J., et al. (1992) Seropositivity to Hepatitis C Virus in Saudi Hemodialysis Patients. Vox Sanguinis, 62, 94-97. http://dx.doi.org/10.1111/j.1423-0410.1992.tb01177.x

[10] Al-Furayh, O., Sobh, M. and Buali, A.R. (1992) Hepatitis C Virus Infection in Chronic Hemodialysis Patients, a Clinicopathologic Study. Nephrology Dialysis \& Transplant, 7, 327-332.

[11] Al-Jiffri, A.M., Fadag, R.B., Ghabrah, T.M. and Ibrahim, A. (2007) Hepatitis C Virus Infection among Patients on Hemodialysis in Jeddah: A Single Center Experience. Saudi Journal of Kidney Disease \& Transplantation, 14, 84-89.

[12] Al-Muhanna FA (1995). Hepatitis C virus infection among hemodialysis patients in the Eastern region of Saudi Arabia. Saudi Journal of Kidney Disease \& Transplantation,6, 125-127.

[13] Al-Shohaib, S.S., Abdelaal, M.A., Zawawi, T.H., Abbas, F.M., Shaheen, F.A., et al. (1995) The Prevalence of Hepatitis C Virus Antibodies among Hemodialysis Patients in Jeddah Area, Saudi Arabia. Saudi Journal of Kidney Disease \& Transplantation, 6, 128-131.

[14] Bernieh, B., Allam, M., Halepota, A., Mohamed, A.O., Parkar, J., et al. (1995) Prevalence of Hepatitis C Virus Antibodies in Hemodialysis Patients in Madinah Al-Munawarah. Saudi Journal of Kidney Disease \& Transplantation, 6, 132-135.

[15] Shaheen, F.A.M., Huraib, S.O. and Al-Rasheed, R. (1995) Prevalence of Hepatitis C Antibodies among Hemodialysis Patients in the Western Province of Saudi Arabia. Saudi Journal of Kidney Disease \& Transplantation, 6, 136-139.

[16] Al Meshari, K., Al Ahdal, M., Alfurayh, O., Ali, A., De Vol, E. and Kessie, G. (1995) New Insights into Hepatitis C Virus Infection of Hemodialysis Patients: The Implications. American Journal of Kidney Disease, 25, 572-578. http://dx.doi.org/10.1016/0272-6386(95)90125-6

[17] Alfurayh, O., Sabeel, A., Al Ahdal, M.N., Almeshari, K., Kessie, G., et al. (2000) Hand Contamination with Hepatitis C Virus in Staff Looking after Hepatitis C-Positive Hemodialysis Patients. American Journal of Nephrology, 20, 103106. http://dx.doi.org/10.1159/000013565

[18] Shobokshi, O.A., Serebour, F.E., Skakni, L, Al-Saffy, Y.H. and Ahdal, M.N. (1999) Hepatitis C Genotypes and Subtypes in Saudi Arabia. Journal of Medical Virology, 58, 44-48. http://dx.doi.org/10.1002/(SICI)1096-9071(199905)58:1<44::AID-JMV6>3.0.CO;2-U

[19] Al-Mugeiren, M., Al-Rasheed, S., Al-Salloum, A., El-Zouki, A., Al-Sohaibani, M., et al. (1996) Hepatitis C Virus Infection in Two Groups of Paediatric Patients: One Maintained on Haemodialysis and the Other on Continuous Ambulatory Peritoneal Dialysis. Annals of Tropical Paediatrics, 16, 335-339.

[20] Soyannwo, M.A., Khan, N., Kommajosyula, S., Abdel Rahman, A.R., Khadaji, M., et al. (1996) Hepatitis C Anti- 
bodies in Haemodialysis and Pattern of End-Stage Renal Failure in Gassim, Saudi Arabia. African Journal of Medicine 7 Medical Sciences, 25, 13-22.

[21] White, A.G., Leheny, W., Kuchipudi, P., Varghese, M., Al Riyami, H., et al. (1999) Histocompatibility Antigens in Omanis: Comparison with Other Gulf Populations and Implications for Disease Association. Annals of Saudi Medicine, 19, 193-196.

[22] Sheth, K.V., Edwards, J.A. and Godwin, J.T. (1987). Study of the HLA Gene and Antigen Frequency from a Saudi Arabian Hospital. Tissue Antigens, 25, 156-162. http://dx.doi.org/10.1111/j.1399-0039.1985.tb00430.x

[23] Hadhoud, A., Abdulaziz, A.M., Menawi, L.A., Shaheen, F.A., Abdulghaffar, A., et al. (2003) The Relationship between HLA Typing and HCV Infection and Outcome of Renal Transplantation in HCV Positive Patients. Experimental \& Clinical Transplantation, 1, 19-25.

[24] Fitzmaurice, K., Petrovic, D., Ramamurthy, N., Simmons, R., Merani, S., et al. (2011) Molecular Footprints Reveal the Impact of the Protective HLA-A*03 Allele in Hepatitis C Virus Infection. Gut, 60, 1563-1571. http://dx.doi.org/10.1136/gut.2010.228403

[25] Cangussu, L.O., Teixeira, R., Campos, E.F., Rampim, G.F., Mingoti, S.A., et al. (2011) HLA Class II Alleles and Chronic Hepatitis C Virus Infection. Scandanavian Journal of Immunology, 74, 282-287. http://dx.doi.org/10.1111/j.1365-3083.2011.02568.x 